\title{
Experimental and Quantum Mechanical Investigation of N-heterocyclic Carbene Palladium Complex: Synthesis and Antibacterial Activity
}

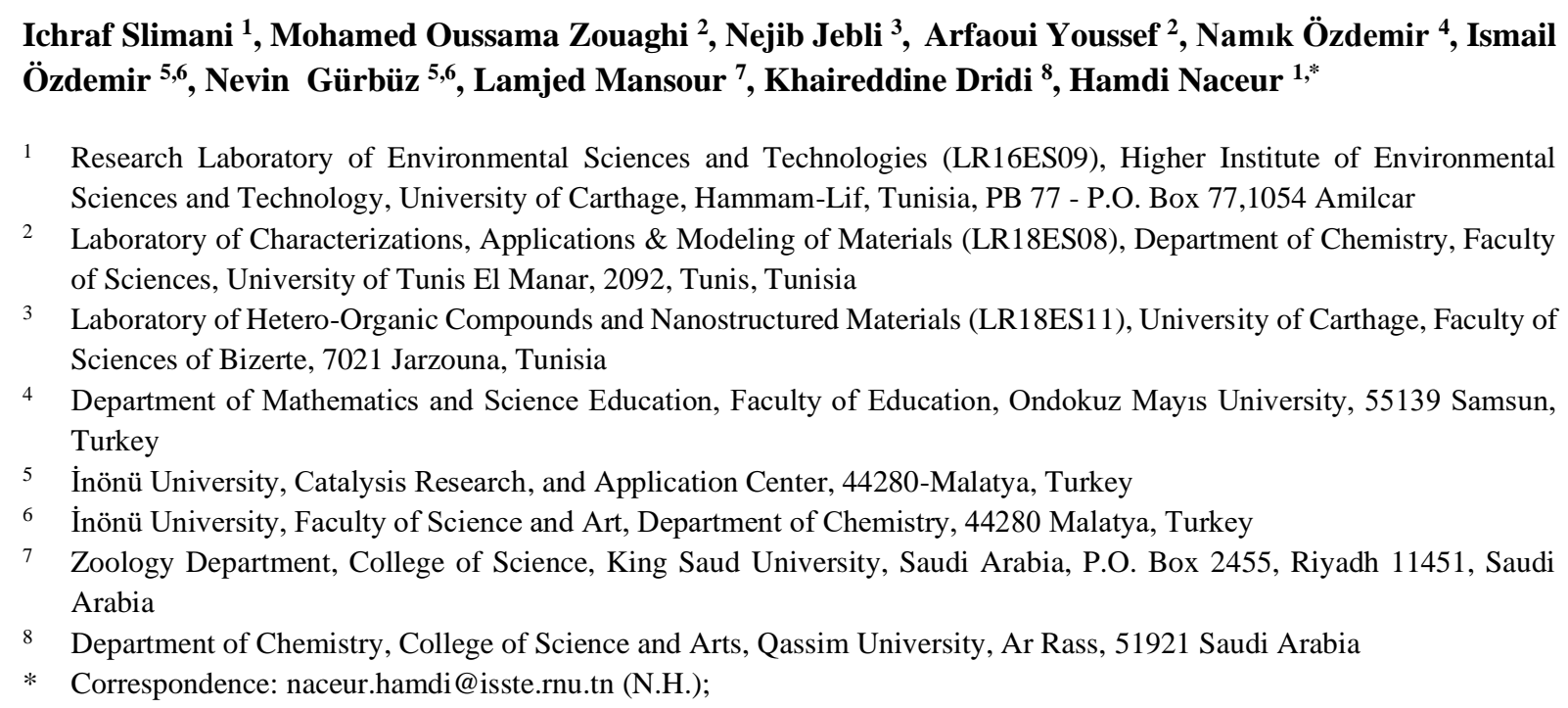

Scopus Author ID 55508562900

Received: 4.10.2021; Revised: 10.11.2021; Accepted: 14.11.2021; Published: 2.12.2021

\begin{abstract}
In this study, we report the synthesis, characterization, and biological activity of Pd-NHCPEPPSI complex 2a. Further confirmations of structural details were provided by a single-crystal Xray. A single crystal of $\mathbf{2 a}$ shows that the coordination geometry around Pd slightly distorted squareplanar geometry. Intermolecular interactions have been studied through the NBO analyses. Structural parameters and spectroscopic properties of the complexes are well interpreted by DFT and TD-DFT calculations. Moreover, the complex 2a showed a remarkable antimicrobial effect against Micrococcus luteus LB 14110mm, Listeria monocytogenes ATCC 19117, Salmonella typhimurium ATCC 14028, Staphylococcus aureus ATCC 6538, Pseudomonas aeruginosa, and Candida albicans.
\end{abstract}

Keywords: DFT; N-heterocyclic carbene; palladium; PEPPSI complex; X-ray crystallography.

(C) 2021 by the authors. This article is an open-access article distributed under the terms and conditions of the Creative Commons Attribution (CC BY) license (https://creativecommons.org/licenses/by/4.0/).

\section{Introduction}

The first successful isolation and characterization of an N-heterocyclic carbene in 1991 introduced a novel category of organic compounds to the world of research [1]. From their beginnings as academic oddities, $\mathrm{N}$-heterocyclic carbenes are now some of organic chemistry's most important tools, with many applications in commercially important processes. Over the last two decades, stable NHCs have been used for designing a range of catalysts employing $\mathrm{Pd}(\mathrm{II}), \mathrm{Cu}(\mathrm{I}), \mathrm{Ni}(\mathrm{II}), \mathrm{Fe}(0), \mathrm{Zn}(\mathrm{II}), \mathrm{Ag}(\mathrm{I}), \mathrm{Au}(\mathrm{I} / \mathrm{III}), \mathrm{Ru}(\mathrm{II})$, and $\mathrm{Rh}$ (I) metal-based precursors. These catalysts were utilized for different organic transformations, such as the Suzuki-Miyaura cross-coupling reaction and $\mathrm{C}-\mathrm{H}$ bond activation [2-8]. Organ and co-workers reported in 2006 a new class of Pd(II) precatalysts, called Pd-PEPPSI (PEPPSI = Pyridine Enhanced Precatalyst Preparation, Stabilization, and Initiation) [9]. Pd-PEPPSI precatalysts have been shown to be 
highly stable in the air allowing for easy storage and handling [10-13]. Moreover, these precatalysts have been reported as very efficient in several $\mathrm{C}-\mathrm{C}$ bond-forming cross-coupling reactions [14-17].

In this paper, the results of crystal structure determination, spectroscopy, and theoretical modeling of NHC-palladium(II) complex 2a are presented and discussed. Furthermore, this complex showed a remarkable antimicrobial effect against Micrococcus luteus LB 14110, Listeria monocytogenes ATCC 19117, Salmonella typhimurium ATCC 14028, Staphylococcus aureus ATCC 6538, Pseudomonas aeruginosa, and Candida albicans.

\section{Materials and Methods}

\subsection{General remarks.}

The Pd-PEPPSI complex (2a) was synthesized (Scheme 1) according to the published procedure [18]. IR spectra were recorded on ATR unit in the range of 400-4000 cm-1 with Perkin Elmer Spectrum 100 Spectrophotometer ( The samples were analyzed by transmittance with $\mathrm{KBr}$ because $\mathrm{KBr}$ has a transmittance of $100 \%$ in the range of wavenumber (4000-400). Therefore, It doesn't show or exhibit absorption in this range.). The electronic absorption spectra were recorded on a Cary-400 UV-visible spectrophotometer connected to a Cary data acquisition system using 1-cm matched silica cells.

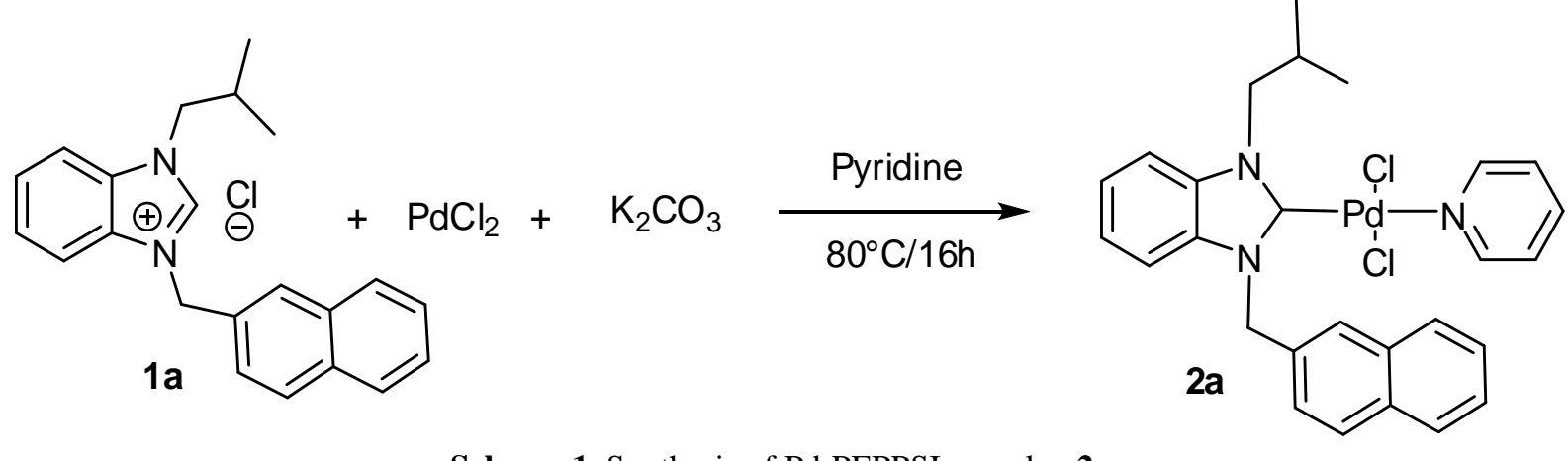

Scheme 1. Synthesis of Pd-PEPPSI complex 2a.

\subsection{X-ray crystallography.}

X-ray diffraction data were collected on an STOE IPDS II diffractometer at room temperature using graphite-monochromated $\mathrm{MoK} \alpha$ radiation by applying the $\omega$-scan method. Data collection and cell refinement were carried out using X-AREA [19], while data reduction was applied using X-RED32 [19]. The structure was solved by direct methods with SIR2019 [20] and refined by means of the full-matrix least-squares calculations on $F^{2}$ using SHELXL2018 [21]. All $\mathrm{H}$ atoms were located in difference maps and then treated as riding atoms, fixing the bond lengths at $0.98,0.93,0.97$, and $0.96 \AA$ for methine $\mathrm{CH}$, aromatic $\mathrm{CH}, \mathrm{CH}_{2}$, and $\mathrm{CH}_{3}$ atoms, respectively. The isopropyl methyl atom $\mathrm{C} 10$ was disordered over two sites, and the refined site-occupancy factors are $0.537(7) / 0.463(7) \%$. The displacement parameters of the $\mathrm{H}$ atoms were fixed at $U_{\text {iso }}(\mathrm{H})=1.2 U_{\text {eq }}\left(1.5 U_{\text {eq }}\right.$ for $\left.\mathrm{CH}_{3}\right)$. Crystal data, data collection, and structure refinement details are given in Table 1. A molecular graphic was generated by using OLEX2 [22]. CCDC 2084749 contains the supplementary crystallographic data for the compound reported in this article. These data can be obtained free of charge on application to CCDC, 12 Union Road, Cambridge CB2 1EZ, UK [Fax: +44 1223336 033, e-mail: deposit@ccdc.cam.ac.uk, https://www.ccdc.cam.ac.uk/structures/]. 
Table 1. Crystal data and structure refinement parameters for Pd-PEPPSI complex $2 \mathbf{a}$.

\begin{tabular}{|c|c|}
\hline CCDC depository & 2084749 \\
\hline Color/shape & Yellow/prism \\
\hline Chemical formula & {$\left[\mathrm{PdCl}_{2}\left(\mathrm{C}_{22} \mathrm{H}_{22} \mathrm{~N}_{2}\right)\left(\mathrm{C}_{5} \mathrm{H}_{5} \mathrm{~N}\right)\right]$} \\
\hline Formula weight & 570.81 \\
\hline Temperature $(\mathrm{K})$ & $296(2)$ \\
\hline Wavelength $(\AA)$ & $0.71073 \mathrm{MoK} \alpha$ \\
\hline Crystal system & Monoclinic \\
\hline Space group & $P 2_{1} / n$ (No. 14$)$ \\
\hline \multicolumn{2}{|l|}{ Unit cell parameters } \\
\hline$a, b, c(\AA)$ & $9.2530(4), 12.4840(6), 21.9892(9)$ \\
\hline$\alpha, \beta, \gamma\left({ }^{\circ}\right)$ & $90,93.781(3), 90$ \\
\hline Volume $\left(\AA^{3}\right)$ & $2534.54(19)$ \\
\hline$Z$ & 4 \\
\hline$D_{\text {calc. }}\left(\mathrm{g} / \mathrm{cm}^{3}\right)$ & 1.496 \\
\hline$\mu\left(\mathrm{mm}^{-1}\right)$ & 0.963 \\
\hline Absorption correction & Integration \\
\hline$T_{\min .}, T_{\max .}$ & $0.6503,0.8883$ \\
\hline$F_{000}$ & 1160 \\
\hline Crystal size $\left(\mathrm{mm}^{3}\right)$ & $0.76 \times 0.19 \times 0.15$ \\
\hline Diffractometer & STOE IPDS II \\
\hline Measurement method & $\omega$ scan \\
\hline Index ranges & $-12 \leq h \leq 12,-16 \leq k \leq 15,-26 \leq l \leq 28$ \\
\hline$\theta$ range for data collection $\left(^{\circ}\right)$ & $1.877 \leq \theta \leq 27.661$ \\
\hline Reflections collected & 14031 \\
\hline Independent/observed reflections & $5878 / 3772$ \\
\hline$R_{\text {int. }}$ & 0.0416 \\
\hline Refinement method & Full-matrix least-squares on $F^{2}$ \\
\hline Data/restraints/parameters & $5878 / 44 / 311$ \\
\hline Goodness-of-fit on $F^{2}$ & 0.882 \\
\hline Final $R$ indices $[I>2 \sigma(I)]$ & $R_{1}=0.0367, w R_{2}=0.0748$ \\
\hline$R$ indices (all data) & $R_{1}=0.0721, w R_{2}=0.0826$ \\
\hline$\Delta \rho_{\text {max. }}, \Delta \rho_{\text {min. }}\left(\mathrm{e} / \AA^{3}\right)$ & $0.47,-0.38$ \\
\hline
\end{tabular}

\subsection{Computational studies.}

All molecular calculations of optimized structures were fully optimized in the gas phase at the DFT level of theory [23-25] using a mixed basis set: $6-311 \mathrm{G}++(2 \mathrm{~d}, 2 \mathrm{p})$ for the $\mathrm{H}, \mathrm{C}, \mathrm{N}$, and $\mathrm{Cl}$ atoms; LANL2TZ for the palladium in combination with a collection of exchangecorrelation (xc) functionals: B3LYP [26-28], M06-2X [29], and $\omega$ B97X-D [30]. Also, correction for basis set superposition error (BSSE) [31] is often applied to calculating the complexation energies. With the fully optimized geometry structure, we have obtained on the succeeding the corresponding electronic structure HOMO (highest occupied molecular orbital), LUMO (lowest unoccupied molecular orbital), and the Molecular Electrostatic Potential surface [32].

In order to obtain UV absorption spectra, 30 lowest electronic excitation energies $\left(\Delta E_{0 n}\right)$ and oscillator strengths $\left(f_{0 n}\right)$ were computed using the TDDFT method [33-35], again with a selection of xc functionals including global hybrids (B3LYP, M06-2X) and rangeseparated hybrid ( $\omega$ B97X-D) and the $6-311 \mathrm{G}++(2 \mathrm{~d}, 2 \mathrm{p}) / \mathrm{LANL} 2 \mathrm{TZ}$ mixed basis set. The optical UV absorption spectra were simulated by associating each transition with a Gaussian function having a full width at half maximum (FWHM) of $0.1 \mathrm{eV}$. The NBO analyses [36, 37] were also calculated to investigate the charge transfer between the different fragments of the Pd(II) complex. CT excitations dominated the UV absorption spectra for push-pull systems like metal complexes and were subjected to a detailed analysis [38]. Each transition is characterized by excitation energy between the ground $(0)$ and $\mathrm{n}^{\text {th }}$ excited states $\left(\Delta E_{o p t}=\right.$ $\left.\Delta E_{0 n}=E_{n}-E_{0}\right)$, and its associated transition dipole moment: 


$$
\mu_{0 n}=\langle 0|\hat{\mu}| n\rangle
$$

Radiative processes are governed by the oscillator strength of the transition, which is related to the transition dipole moment:

$$
f_{0 n}=\frac{2}{3} \Delta E_{0 n}\left|\mu_{0 n}\right|^{2}
$$

The CT character of the excitations can be determined from the difference of electronic density between the ground and excited states, $\Delta \rho(\vec{r})$, following the procedure described by Le Bahers et al. [38]. Using this method, the distance between the barycenters of the negative and positive $\Delta \rho(\vec{r})$ defines the charge-transfer distance $\left(d_{C T}\right)$, their integration over the whole space gives the amount of charge transferred $\left(q_{C T}\right)$, while their product gives the CT dipole moment, $\Delta \mu_{C T}=q_{C T} \times d_{C T}$.

All calculations in this work were carried out using the Gaussian 09 software package [39].

\subsection{Antimicrobial activity.}

2.4.1. Microorganisms, media, and growth conditions.

For the antimicrobial determination, microorganisms used as indicators were the two Gram-positive bacteria Staphylococcus aureus (S. aureus) ATCC6538 and Listeria monocytogenes (L. monocytogenes) ATCC 19117, the three Gram-negative bacteria Escherichia coli (E. coli) ATCC 8739, Pseudomonas aeruginosa (P. aeruginosa) ATCC 49189 and Salmonella typhimurium (S. typhimurium) ATCC 14028, and the fungus Candida albicans (C. albicans) ATCC 10231. All these indicator microorganisms were obtained from International Culture Collections (ATCC). The indicator microorganisms were grown overnight in Luria Bertani (LB) medium ( $\mathrm{g} \mathrm{L}^{-1}$ : peptone 10; yeast extract 5 and $\mathrm{NaCl} 5, \mathrm{pH}$ 7.2) under aerobic condition and constant agitation $(200 \mathrm{rpm})$ at $30^{\circ} \mathrm{C}$ for L. monocytogenes ATCC 19117 and S. typhimurium ATCC 14028 and at $37^{\circ} \mathrm{C}$ for E. coli ATCC 8739, S. aureus ATCC6538 and P. aeruginosa ATCC 49189 and then diluted 1:100 in LB media and incubated for $5 \mathrm{~h}$ under constant agitation $(200 \mathrm{rpm})$ at the appropriate temperature. C. albicans ATCC 10231 was cultured at $30{ }^{\circ} \mathrm{C}$ on Sabouraud medium (g L-1: dextrose 40, peptone 10, pH 5.6) under aerobic condition and constant agitation (200 rpm) and then diluted 1:50 in Sabouraud medium and incubated for $5 \mathrm{~h}$ under constant agitation $(200 \mathrm{rpm})$ at $30{ }^{\circ} \mathrm{C}$.

\subsubsection{Agar well diffusion method.}

Agar well diffusion method was employed for the determination of the antimicrobial activity of the synthesized compounds according to Guven et al. (2006) [40]: Briefly, fifteen milliliters of molten agar $\left(45^{\circ} \mathrm{C}\right)$ were poured into sterile Petri dishes (Ø $\left.90 \mathrm{~mm}\right) .50 \mu \mathrm{L}$ of 5 h old culture of the five tested bacteria and $100 \mu \mathrm{L}$ of $5 \mathrm{~h}$ old culture of the fungus $C$. albicans were evenly spread onto the surface of the agar plates of LB agar medium for bacteria and Sabouraud agar medium for C. albicans. Once the plates had been aseptically dried, $5 \mathrm{~mm}$ wells were punched into the agar with a sterile cork borer. $100 \mu \mathrm{L}$ of a solution at $500 \mu \mathrm{g} \mathrm{mL}^{-}$

${ }^{1}$ of each synthesized compound were dispensed into the wells. After staying at $4{ }^{\circ} \mathrm{C}$ for $2 \mathrm{~h}$, the plates were incubated at the appropriate temperature for $24 \mathrm{~h}$ for bacterial strains and $48 \mathrm{~h}$ for $C$. albicans. The antimicrobial activity was assayed by measuring the inhibition zone diameter formed around each well in millimeters. 
2.4.3. Minimum inhibitory concentration (MIC).

(MIC) of the synthesized compounds and the standards ampicillin, kanamycin, and fluconazole (stock solutions at $20 \mathrm{mg} / \mathrm{mL}^{-1}$ ) against the five tested bacteria and C. albicans fungus were determined according to Sellem et al. (2016) [41]. The test was performed in sterile 96-well microplates with a final volume in each microplate well of $100 \mu \mathrm{L}$. Stock solutions of synthesized compounds and standards were serially diluted with dimethyl sulfoxide (DMSO). To each test well, the cell suspension was added to the final inoculum concentration of $106 \mathrm{CFU} \mathrm{mL} \mathrm{m}^{-1}$ of indicator microorganism. The plates were then incubated at appropriate growth conditions of the corresponding indicator microorganism. The (MIC) was defined as the lowest concentration of the synthesized compounds and standards at which the microorganism does not demonstrate visible growth after incubation. Twenty-five $\mu$ of Thiazolyl Blue Tetrazolium Bromide (MTT) at $0.5 \mathrm{mg} \mathrm{mL}^{-1}$ were added to the wells and incubated at room temperature for $30 \mathrm{~min}$. The colorless tetrazolium salt acted as an electron acceptor and was reduced to a red-colored formazan product by the indicator microorganisms. When microbial growth was inhibited, the solution in the well remained clear after incubation with MTT.

For the antimicrobial activity determination (inhibition zones and CMIs), each experiment was carried out simultaneously three times under the same conditions. The diameters of inhibition zones reported in $\mathrm{mm}$ and the MIC values reported in $\mu \mathrm{g} \mathrm{mL}-1$ were similar, and the reported results are the average of the three experiments.

\section{Results and Discussion}

\subsection{Theoretical study.}

3.1.1. Structural study.

Firstly, we have investigated the impact of the xc functionals on the geometric data of the $P d(I I)$ - PEPPSI complex sketched in Figure 1.

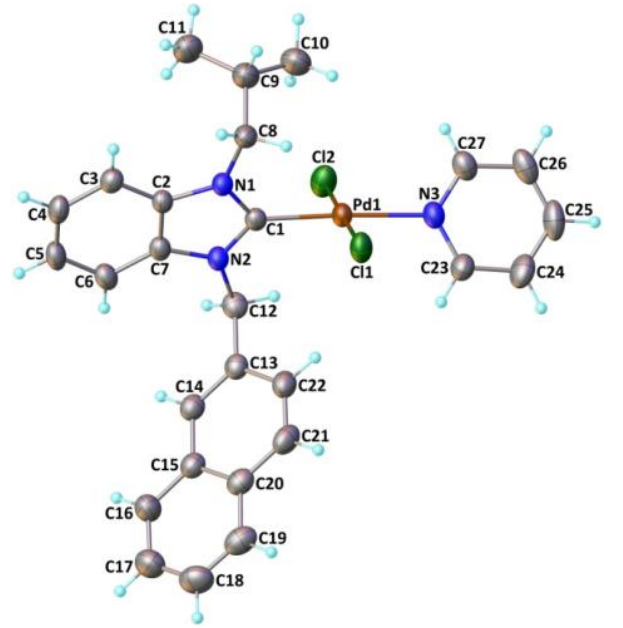

Figure 1. Molecular structure of Pd-PEPPSI complex 2a drawn at 30\% probability level.

Table 2. Geometric parameters (Bond lengths $(\AA)$ and angles $\left(^{\circ}\right)$ ) determined experimentally by X-ray diffraction $(X R D)$ and computed at several XC functionals.

\begin{tabular}{c|c|c|c|c} 
Parameter & $\boldsymbol{X} \boldsymbol{R} \boldsymbol{B}$ & $\boldsymbol{B 3} \boldsymbol{L} \boldsymbol{P}$ & $\boldsymbol{\omega B} \mathbf{B} \boldsymbol{X}-\boldsymbol{D}$ & $\boldsymbol{M 0 6}-\mathbf{2} \boldsymbol{X}$ \\
\hline Pd1-C12 & 2.299 & 2.427 & 2.403 & 2.433 \\
\hline Pd1-Cl3 & 2.298 & 2.427 & 2.403 & 2.433 \\
\hline Pd1-N4 & 2.091 & 2.138 & 2.118 & 2.159
\end{tabular}




\begin{tabular}{c|c|c|c|c}
\hline Parameter & $\boldsymbol{X R D}$ & $\boldsymbol{B 3} \boldsymbol{L Y P}$ & $\boldsymbol{\omega B} \boldsymbol{B} \boldsymbol{X}-\boldsymbol{D}$ & $\boldsymbol{M 0 6}-\mathbf{2 x}$ \\
\hline Pd1-C10 & 1.964 & 1.998 & 1.984 & 1.974 \\
\hline C12-Pd1-C13 & 179.1 & 175.9 & 175.7 & 173.9 \\
\hline N4-Pd1-C10 & 177.0 & 179.4 & 180.0 & 179.8
\end{tabular}

The analysis of Table 2 shows that $\omega B 97 X-D$ (which comprised of $22 \%$ HartreeFock exchange at the short-range and $100 \%$ Hartree-Fock at the long-range) is the most suitable $\mathrm{XC}$ functional to optimize the Pd - PEPPSI complex. The computed geometric parameters at $\omega B 97 X-D$ level are close to those determined by the X-Ray diffraction method (Figure 2).

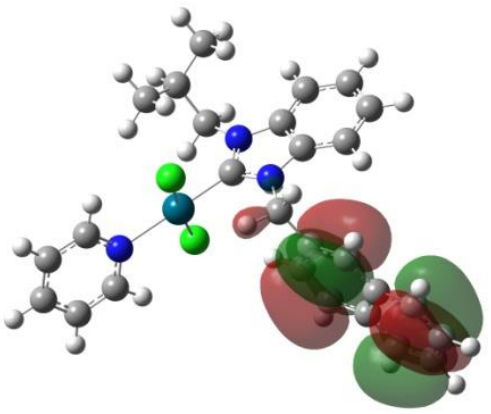

(a)

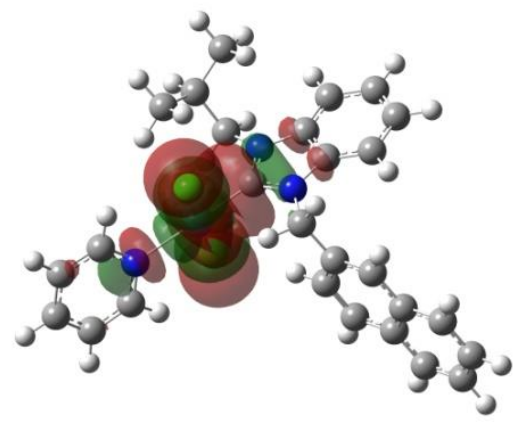

(b)

Figure 2. Localization of frontier molecular orbitals of the complex 2a : (a) HOMO (b) LUMO.

In the case of complex $\mathbf{2 a}$, the HOMO is localized on the naphthalene group, whereas the LUMO is localized on the Pd and the sites concerned with the charge transfer (Figure 3).

\subsubsection{Charge-transfer character.}

In order to investigate the charge transfer between the metal $(P d(I I))$ and its four ligands, we have analyzed the NBO populations before and after the complexation.

To achieve this objective, we have considered an amount of charge $q_{i}$ for the three ligands of the complex $\mathbf{2 a}$ such as explained in Figure 3.

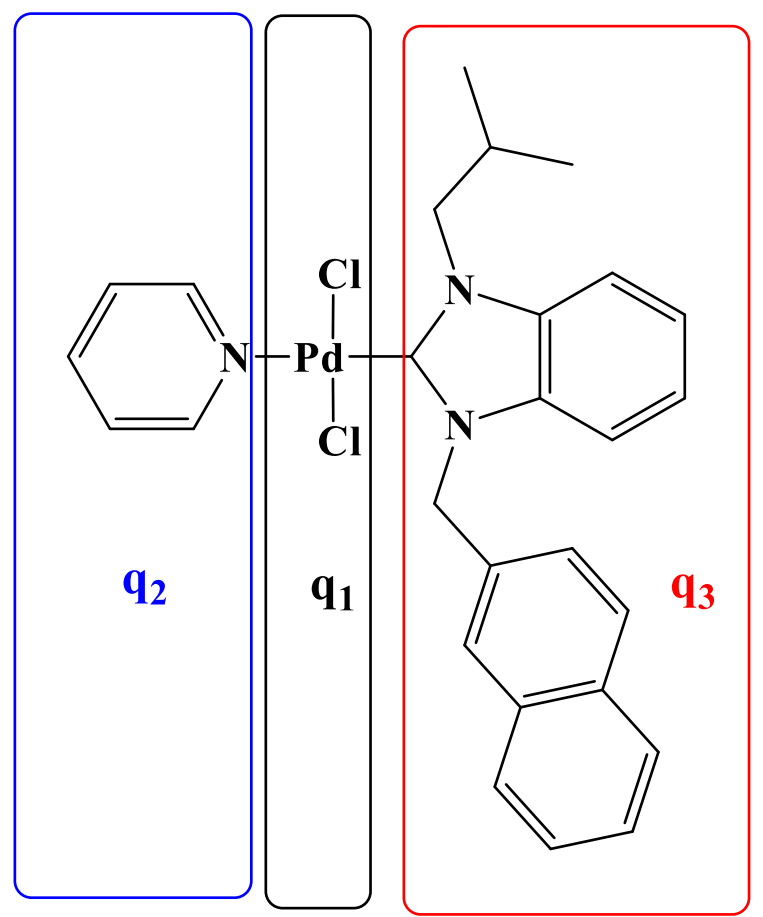

Figure 3. Repartition of the amount of charge $q_{i}$ in complex $\mathbf{2 a}$. 
Table 3. Computed amount charge $\left(q_{i}\right)$ (e) for the three considered ligands of the complex $2 \mathrm{a}$.

\begin{tabular}{c|c|c|c|c|c|c} 
& \multicolumn{3}{|c|}{ Before the complexation } & \multicolumn{3}{c}{ After the complexation } \\
\hline Charge amount $q_{i}$ & $q_{1}$ & $q_{2}$ & $q_{3}$ & $q_{1}$ & $q_{2}$ & $q_{3}$ \\
\hline & 0.000 & 0.000 & 0.000 & -0.733 & 0.237 & 0.496
\end{tabular}

Table 4. Natural electron configuration of Pd(II) complex at $\omega \mathrm{B} 97 \mathrm{X}-\mathrm{d} / 6-311 \mathrm{G}++(2 \mathrm{~d}, 2 \mathrm{p}) / \mathrm{LANL} 2 \mathrm{TZ}$.

\begin{tabular}{c|c} 
Site & Natural Electron Configuration \\
\hline Pd1 & {$[$ core]5S $(0.35) 4 \mathrm{~d}(8.97) 5 \mathrm{p}(0.38) 5 \mathrm{~d}(0.01)$} \\
\hline C12 & {$[\operatorname{core}] 3 \mathrm{~S}(1.90) 3 \mathrm{p}(5.61)$} \\
\hline C13 & {$[\operatorname{core}] 3 \mathrm{~S}(1.90) 3 \mathrm{p}(5.60)$} \\
\hline $\mathbf{N 4}$ & {$[$ core]2S( 1.32$) 2 \mathrm{p}(4.12) 3 \mathrm{p}(0.02)$} \\
\hline C10 & {$[$ core]2S $(0.98) 2 \mathrm{p}(2.59) 3 \mathrm{~S}(0.01) 3 \mathrm{p}(0.03)$}
\end{tabular}

Table 5. Charge transfer parameters of the lowest-energy dominant excitations of selected TT derivatives $\left[q_{C T}\right.$ (e), $d_{C T}(\AA), \Delta \mu_{C T}=q_{C T} \times d_{C T}$ (D)] as calculated at the TDDFT/B3LYP/6-311G++(2d,2p)/LANL2TZ level.

\begin{tabular}{c|c|c|c|c} 
Compound & Excite state number & $\mathbf{q C T}$ & $\mathbf{d}_{\mathbf{C T}}$ & $\boldsymbol{\mu}_{\mathrm{CT}}$ \\
\hline Complex 2a & 1 & 0.722 & 0.174 & 0.603
\end{tabular}

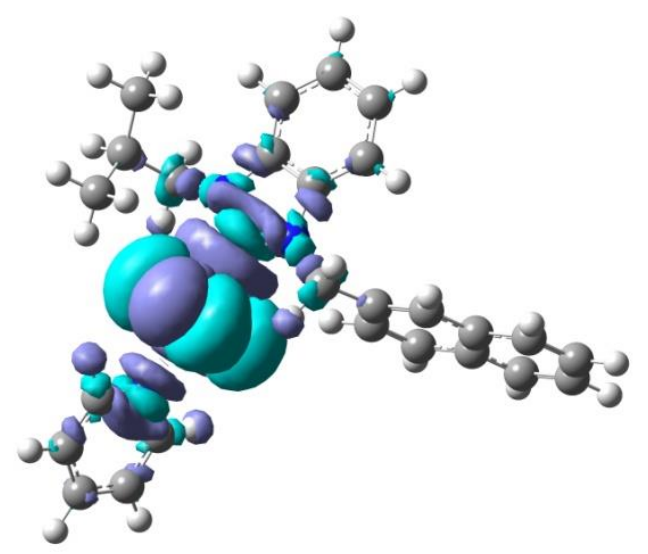

Figure 4. Excitation-induced B3LYP/6-311G++(2d, 2p)/LANL2TZ total electron density difference $[\Delta \rho(\vec{r})=$ $\rho_{\text {excited }}(\vec{r})-\rho_{\text {ground }}(\vec{r})$, isocontour value $0.0004 \mathrm{au}$ ] for the lowest-energy excited state of $\operatorname{Pd}(\mathrm{II})$ complex. (Purple: Positive value/Light Blue: Negative value).

The analysis of Table 3 shows the charge transfer between the three fragments of the complex 2a. We have found a main charge transfer from the imidazole derivative to the $\mathrm{PdCl}_{2}$ fragment with an amount of charge $\left(q_{3}=0.496 \mathrm{e}\right)$. Also, we have reported a second charge transfer from the pyridine ligand to $\mathrm{PdCl}_{2}$ with an amount of charge $\left(q_{2}=0.237 \mathrm{e}\right)$. Furthermore, the analysis of table 4 showed that the valence electron configurations of Pd1 and N4 confirm an important charge transfer from fragment 3 to palladium. Also, the examination of data of Table 5 showed a CT between the ground and the excited state with an amount of charge $q_{C T}$ (0.722e).

\subsubsection{Analysis of Infra-Red and Ultra-violet absorption spectra.}

The experimental (in solid-state) and theoretical (in vacuum) IR spectra of the $\mathrm{Pd}(\mathrm{II})$ complex are given in Figures 5 and 6.

The bands recorded at $2975-3237 \mathrm{~cm}^{-1}$ are attributed to $\mathrm{CH}_{2}$ and $\mathrm{CH}_{3}$ stretching vibrations. In addition, the aromatic $\mathrm{C}=\mathrm{C}$ stretching vibration is seen at 1639,1650 , and 1674 $\mathrm{cm}^{-1}$.

UV-vis studies were employed to confirm the formation of Pd-PEPPSI complex 2a, and the results were provided in Figure 6 and Table 6. In the case of the Carbene-Pd(II) 
complex, two UV peaks are revealed [42,43], and the obtained results at the B3LYP level are in good agreement with the literature.

We have assigned the two obtained UV peaks as follows: The characteristic $\pi-\pi^{*}$ transition of aromatic rings moiety appeared at around $\lambda_{\max }$ of $273 \mathrm{~nm}$ [42]. On the other hand, a broad hump appeared at $314 \mathrm{~nm}$ due to the presence of $\mathrm{d}-\mathrm{d}$ transition (metal to ligand charge transfer-MLCT) of Pd (II) [44]. The MLCT has been confirmed by the NBO analyses and the charge transfer between the ground and excited states.

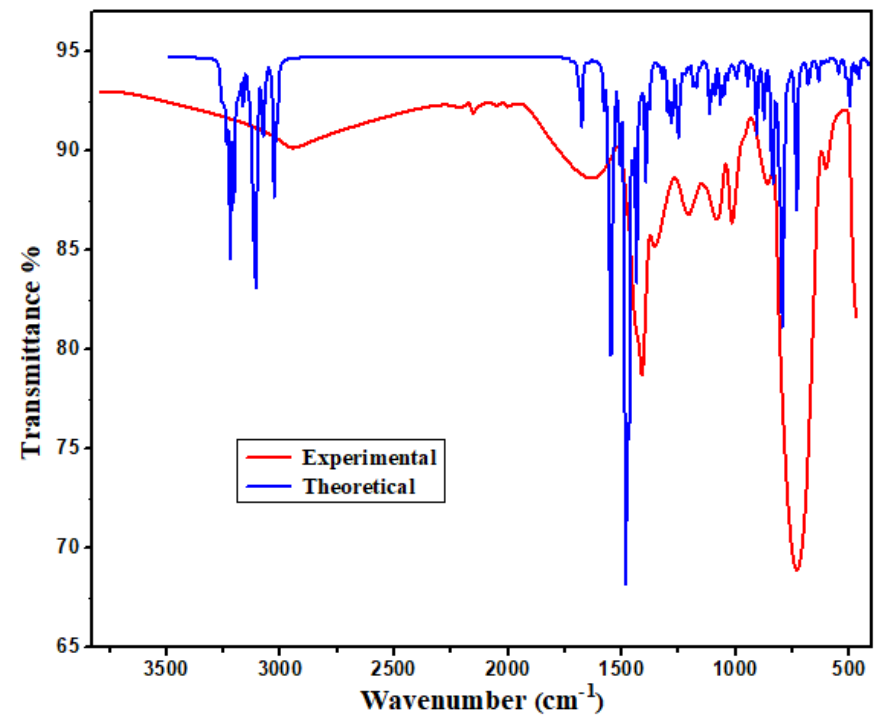

Figure 5. Experimental and computed IR spectra of complex 2a.

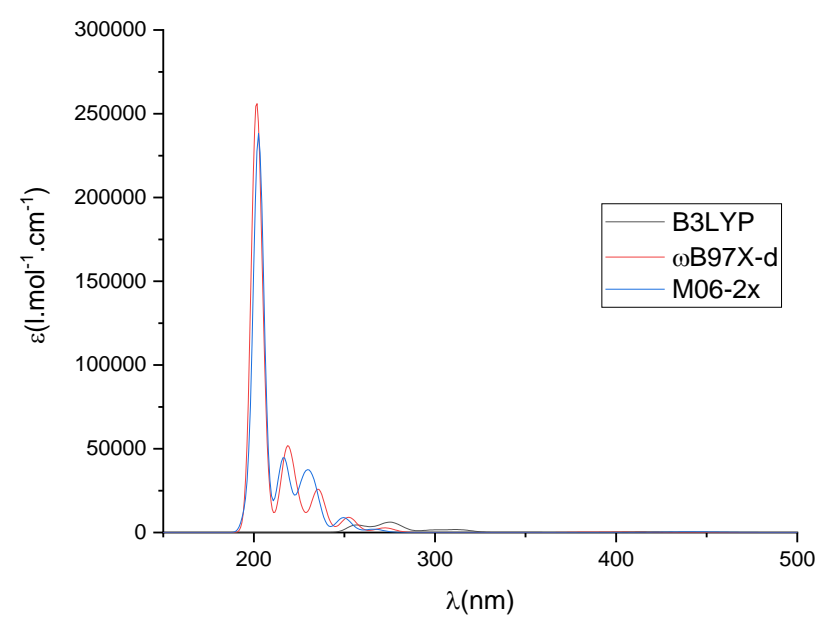

Figure 6. Computed UV absorption spectra of the complex $2 \mathbf{a}$ at the level of XC functionals.

Table 6. Lowest-energy dipole-allowed excited states of complex 2a evaluated at the level of several XC functionals [excitation energies $\left(\Delta E_{0 n}, \mathrm{eV}\right)$, the wavelength of absorption $\left(\lambda_{T D D F T}, \mathrm{~nm}\right.$, as obtained from the simulated spectra), dominant MO pairs describing the excitations and oscillator strengths.

\begin{tabular}{|c|c|c|c|c|}
\hline XC Functional & $\lambda(\mathbf{n m})$ & MOs & $\Delta \boldsymbol{E}_{0 n}$ & $f_{0 n}$ \\
\hline Experimental [41] & $\begin{array}{l}314 \\
263\end{array}$ & & & \\
\hline B3LYP & $\begin{array}{l}314 \\
273\end{array}$ & $\begin{array}{c}\mathrm{H}(-7)-\mathrm{L}(77 \%) \\
\mathrm{H}-\mathrm{L}(+3)(65 \%)\end{array}$ & $\begin{array}{l}3.94 \\
4.53\end{array}$ & $\begin{array}{l}0.01 \\
0.03\end{array}$ \\
\hline$\omega B 97 X-D$ & $\begin{array}{l}272 \\
252 \\
235 \\
224\end{array}$ & $\begin{array}{c}\mathrm{H}(-7)-\mathrm{L}(87 \%) \\
\mathrm{H}-\mathrm{L}(+2)(82 \%) \\
\mathrm{H}(-4)-\mathrm{L}(+3)(44 \%) \\
\mathrm{H}(-4)-\mathrm{L}(12 \%) \\
\mathrm{H}(2-) \mathrm{L}(+3)(14 \%)\end{array}$ & $\begin{array}{l}4.45 \\
4.91 \\
5.26 \\
5.52\end{array}$ & $\begin{array}{l}0.02 \\
0.07 \\
0.16 \\
0.06\end{array}$ \\
\hline
\end{tabular}




\begin{tabular}{c|c|c|c|c}
\hline XC Functional & $\boldsymbol{\lambda}(\mathbf{n m})$ & MOs & $\Delta \boldsymbol{E}_{\mathbf{0 n}}$ & $\boldsymbol{f}_{\mathbf{0 n}}$ \\
\hline M06-2X & 267 & $\mathrm{H}(-6)-\mathrm{L}$ & 4.64 & 0.01 \\
& 249 & $\mathrm{H}(-1) \mathrm{L}(+2)$ & 4.97 & 0.06 \\
& 233 & $\mathrm{H}(-3)-\mathrm{L}(+3)$ & 5.32 & 0.18 \\
& 227 & $\mathrm{H}(-9)-\mathrm{L}$ & 5.45 & 0.19
\end{tabular}

\section{Biological activities}

The Pd-NHC-PEPPSI complex $\mathbf{2 a}$ was investigated for antibacterial against both grams $(+) /(-)$ bacterias. The tests were carried out at a concentration of $0.5 \mathrm{mg} / \mathrm{mL}$ of the test sample with standard AMC. As reported earlier, DMSO did not exhibit any antimicrobial activity $[45,46]$. The antimicrobial activities of the Pd-NHC-PEPPSI complex 2a are summarized in Table 7

The Pd-NHC-PEPPSI complex 2a tested in this study for its antimicrobial activity displayed a very good performance. Compound 2a showed good activity against all types of bacteria especially, Micrococcus luteus LB 14110: 24 $\pm 2.17 \mathrm{~mm}$ (with significant difference of $\mathrm{P}<0.01$ in comparison to positive control), Listeria monocytogenes ATCC 19117: 25 $\pm 2.12 \mathrm{~mm}$, Salmonella typhimurium ATCC 14028: $26 \pm 2.15 \mathrm{~mm}$, Staphylococcus aureus ATCC 6538: $25 \pm 2.11 \mathrm{~mm}$, Pseudomonas aeruginosa: $28 \pm 2.11 \mathrm{~mm}$ and Candida albicans $26 \pm 2.13 \mathrm{~mm}$.

Table 7. Zone of bacterial inhibition measured in mm of Pd-NHC-PEPPSI 2a.

\begin{tabular}{c|c|c|c|c|c|c}
$\begin{array}{c}\text { Micro } \\
\text { organisms }\end{array}$ & $\begin{array}{c}\text { Micrococcus } \\
\text { luteus } \\
\text { LB 14110 }\end{array}$ & $\begin{array}{c}\text { Listeria } \\
\text { monocytogenes } \\
\text { ATCC 19117 }\end{array}$ & $\begin{array}{c}\text { Salmonella } \\
\text { Typhimurium } \\
\text { ATCC 14028 }\end{array}$ & $\begin{array}{c}\text { Staphylococcus } \\
\text { aureus } \\
\text { ATCC 6538 }\end{array}$ & $\begin{array}{c}\text { Pseudomonas } \\
\text { aeruginosa }\end{array}$ & $\begin{array}{c}\text { Candida } \\
\text { albicans }\end{array}$ \\
\hline 2a & $24 \pm 2.17^{*}$ & $25 \pm 2.12^{*}$ & $26 \pm 2.15^{*}$ & $25 \pm 2.11^{*}$ & $28 \pm 2.11^{*}$ & $26 \pm 2.13^{*}$ \\
\hline AMC & $25 \pm 2.1^{*}$ & $24 \pm 2.2^{*}$ & $23 \pm 2.3^{*}$ & $21 \pm 2.1^{*}$ & $20 \pm 2.2^{*}$ & $20 \pm 2 .^{*}$
\end{tabular}

This table indicates the antibacterial activities of the tested compound in inhibition zones by $\mathrm{mm}$. The values are means \pm S.D. AMC (ampicillin) was used as a positive control drug. $* \mathrm{P}<0.01$.

\subsection{Minimum inhibitory concentration (MIC) determination.}

Minimum inhibitory concentration (MIC) of the synthesized compound 2a and the standard ampicillin were assessed using the microdilution method against three indicator microorganisms: the two Gram-positive bacteria L. monocytogenes and S. aureus, the Gramnegative bacterium S. typhimurium ATCC 14028.

The antibacterial activity of the Pd-NHC-PEPPSI complex 2a is reported in the minimum inhibitory concentration (MIC) values, which are the lowest concentration of an antimicrobial compound that visibly inhibits the growth of the bacteria after overnight incubation. The antimicrobial activity of complex $\mathbf{2 a}$ was evaluated against Listeria monocytogenes ATCC 19117, Salmonella typhimurium ATCC 14028, and Micrococcus luteus and was compared with ampicillin. All were used to treat general bacterial infections. The MIC value of the tested complex is presented in Table 8 .

The MICs values range from 0.125 to $1.15 \mathrm{mg}$ mL-1 against Listeria monocytogenes ATCC 19117, Salmonella Typhimurium ATCC 14028, and Micrococcus luteus. The lowest MIC value was obtained against Listeria monocytogenes ATCC 19117. The Pd-NHC-PEPPSI complex 2a showed a weak performance compared with ampicillin. 
Table 8. The minimal bacterial inhibitory concentration measured in $\mathrm{mg} / \mathrm{mL}$ of Pd-PEPPSI complex $\mathbf{2 a}$.

\begin{tabular}{c|c|c}
$\begin{array}{c}\text { Microorganism } \\
\text { indicator }\end{array}$ & Compound & MIC (mg/ml) \\
\hline \multirow{2}{*}{$\begin{array}{c}\text { Listeria } \\
\text { monocytogenes } \\
\text { ATCC 19117 }\end{array}$} & Ampicillin & $0.125 \pm 0.11$ \\
\cline { 2 - 3 } & & $0.039 \pm 0.12$ \\
\hline $\begin{array}{c}\text { Salmonella } \\
\text { Typhimurium } \\
\text { ATCC 14028 }\end{array}$ & $\mathbf{2 a}$ & $1.15 \pm 0.12$ \\
\cline { 2 - 3 } & Ampicillin & $0.039 \pm 0.11$ \\
\hline \multirow{2}{*}{\begin{tabular}{l} 
Micrococcus luteus \\
\cline { 2 - 3 }
\end{tabular}} & $\mathbf{2 a}$ & $0.325 \pm 0.12$ \\
\cline { 2 - 3 } & Ampicillin & $0.039 \pm 0.12$
\end{tabular}

This table indicates the Minimal bacterial inhibitory concentration of the tested compound $\mathbf{2}$. The values are means \pm S.D. AMC (ampicillin) was used as a control positive drug. $* \mathrm{P}<0.01$.

\section{Conclusions}

In conclusion, Pd-NHC-PEPPSI complex 2a was synthesized and characterized by IR, UV, X-ray, and molecular modeling techniques. Computational studies on the structural and spectroscopic features of the complex were done at the DFT level of theory. Furthermore, The Pd-NHC-PEPPSI complexes $\mathbf{2 a}$ showed better antimicrobial activity than the AMC (ampicillin).

\section{Funding}

This research received no external funding.

\section{Acknowledgments}

This work was supported by the Research Supporting Project (RSP- 2021/75), King Saud University (Riyadh, Saudi Arabia).

\section{Conflicts of Interest}

The authors declare no conflict of interest.

\section{References}

1. Arduengo III, A.J.; Harlow, R.L.; Kline, M. A. Stable crystalline carbene. J Am Chem Soc 1991, 113, 361363, https://doi.org/10.1021/ja00001a054.

2. Lei, P.; Meng, G.; Ling, Y.; An, J.; Szostak, M. Pd-PEPPSI: Pd-NHC precatalyst for Suzuki-Miyaura crosscoupling reactions of amides. J Org Chem 2017, 82, 6638-6646, https://doi.org/10.1021/acs.joc.7b00749.

3. Li, G.; Lei, P.; Szostak, M.; Casals-Cruañas, E.; Poater, A.; Cavallo, L.; Nolan, S.P. Mechanistic Study of Suzuki-Miyaura Cross-Coupling Reactions of Amides Mediated by [Pd (NHC)(allyl) Cl] Precatalysts. ChemCatChem 2018, 10, 3096-3106, https://doi.org/10.1002/cctc.201800511.

4. Kaloğlu, N.; Özdemir, İ. PEPPSI-Pd-NHC catalyzed Suzuki-Miyaura cross-coupling reactions in aqueous media. Tetrahedron 2019, 75, 2306-2313, https://doi.org/10.1016/j.tet.2019.02.062.

5. Waseem, M., Rami, S., Wissam, I., Mohammed, F., El Ali, B. Synthesis, crystal structure, and catalytic activity of bridged-bis (N-heterocyclic carbene) palladium(II) complexes in selective Mizoroki-Heck crosscoupling reactions. Polyhedron 2021, 207, 115371, https://doi.org/10.1016/j.poly.2021.115371.

6. Sofie, M.P.; Vanden, B.; Catherine, S.J. Cazin, Manganese-N-heterocyclic carbene (NHC) complexes - An overview. Polyhedron 2021, 205, 115371, https://doi.org/10.1002/cctc.201800241. 
7. Katagiri, T.; Amao, Y. Recent advances in light-driven $\mathrm{C}-\mathrm{H}$ bond activation and building $\mathrm{C}-\mathrm{C}$ bonds with CO 2 as a feedstock for carbon capture and utilization technology. Green Chemistry 2020, 22, 6682-6713, https://doi.org/10.1039/D0GC01796E.

8. Shariatipour, M.; Salamatmanesh, A.; Nejad, M.J.; Heydari, A. Imidazole-aryl coupling reaction via CH bond activation catalyzed by palladium supported on modified magnetic reduced graphene oxide in alkaline deep eutectic solvent. Catal Commun 2020, 135, 105890, https://doi.org/10.1016/j.catcom.2019.105890.

9. Can, H.; Jiahao, L.; Hai-Hua, H.; Zhuofeng, K. Recent progress in electro- and photo-catalytic CO2 reduction using N-heterocyclic carbene transition metal complexes. Polyhedron 2021, 203, 115147, https://doi.org/10.1016/j.poly.2021.115147.

10. Gokanapalli, A.; Motakatla, V.K.R.; Peddiahgari, V.G.R.. Investigation of Pd-PEPPSI catalysts and coupling partners towards direct C2-arylation/heteroarylation of benzoxazole. Appl Organomet Chem 2021, e6296, https://doi.org/10.1002/aoc.6296.

11. Guillet, S.G.; Voloshkin, V.A.; Saab, M.; Beliš, M.; Van Hecke, K.; Nahra, F.; Nolan, S.P. Understanding existing and designing novel synthetic routes to Pd-PEPPSI-NHC and Pd-PEPPSI-PR 3 precatalysts. ChemComm 2020, 56, 5953-5956, https://doi.org/10.1039/D0CC02262D.

12. Aziza, M.; Abdullah, S. A.; Ismail, Ö.; Nevin, G.; Hamdi, N. A new PEPPSI type N-heterocyclic carbene palladium(II) complexes and its efficiency as a catalyst for Mizoroki-Heck cross-coupling reactions in water : Synthesis, Characterization and their antimicrobial and Cytotoxic activities. Journal of Molecular Structure 2021, 234, 130204, https://doi.org/10.1016/j.molstruc.2021.130204.

13. Miroslav, D.; Petar, P.; Nikolay, G.V. N-heterocyclic bis-carbene palladium complexes derived from functionalized naphthalimides - Synthesis, Structure elucidation and DFT study. Journal of Molecular Structure 2021, 1230, 129944, https://doi.org/10.1016/j.molstruc.2021.129944.

14. Ceren, A.; Namık, O.; Mert, O. K.; Bülent, A.; Ismail, O. Synthesis, crystal structures and catalytic activities of palladium complexes with coumarin-functionalised N-heterocyclic carbene ligands, Inorganic Chemistry Communications 2021, 131, 108755, https://doi.org/10.1016/j.inoche.2021.108755.

15. Ahmadvand, Z.; Bayat, M.; Zolfigol, M.A. Toward prediction of the precatalyst activation mechanism through the cross-coupling reactions: Reduction of $\mathrm{Pd}$ (II) to $\mathrm{Pd}(0)$ in precatalyst of the type $\mathrm{Pd}$ PEPPSI. J Comput Chem 2020, 41, 2296-2309, https://doi.org/10.1002/jcc.26393.

16. Borah, D.; Saha, B.; Sarma, B.; Das, P. A new PEPPSI type N-heterocyclic carbene palladium (II) complex and its efficiency as a catalyst for Mizoroki-Heck cross-coupling reactions in water. J Chem Sci 2020, 132, 1-10, https://doi.org/10.1007/s12039-020-1754-y.

17. Kumar, A.; Kumar, M.; Verma, A.K. Well-Defined Palladium N-Heterocyclic Carbene Complexes: Direct C-H Bond Arylation of Heteroarenes. J Org Chem 2020, 85, 13983-13996, https://doi.org/10.1021/acs.joc.0c02024.

18. Slimani, I.; Mansour, L.; Özdemir, I.; Gürbüz, N.; Hamdi, N. Synthesis, characterization and catalytic activity of PEPPSI-type palladium-NHC complexes. Inorganica Chim. Acta 2021, 515, 120043, https://doi.org/10.1016/j.ica.2020.120043.

19. Nagaraju, P.; Varnakumar, G.; Debasis, S. N-heterocyclic carbene bearing thermoresponsive poly(NIPAM) supported palladium (II) complex: Synthetic strategy and application. Journal of Organometallic Chemistry 2020, 913, 121196.

20. Mert, O.K. Comparison of the catalytic performances of bridged bi-metallic and nonbridged mono-metallic PEPPSI type palladium N-heterocyclic carbene complexes. Inorganic Chemistry Communications 2021, 116, 107890, https://doi.org/10.1016/j.inoche.2020.107890.

21. Thomas, S.; Enrica, B.; Isabella, C.; Flavio, R.; Nicola, D.; Fabiano, V. Synthesis and comparative study of the anticancer activity of $\mathrm{g} 3$-allyl palladium(II) complexes bearing N-heterocyclic carbenes as ancillary ligands. Polyhedron 2020, 186, 114607, https://doi.org/10.1016/j.poly.2020.114607.

22. Murat, K.; Serpil, D.D.; Ismail, O. The first used butylene linked bis(N-heterocyclic carbene)palladiumPEPPSI complexes in the direct arylation of furan and pyrrole. Journal of Organometallic Chemistry 2020, 915, 121236, https://doi.org/10.1016/j.jorganchem.2020.121236.

23. Waseem, M.; Rami, S.; Mohammed, F.; and Bassam, El Ali. Soft Heteroleptic N-Heterocyclic Carbene Palladium(II) Species for Efficient Catalytic Routes to Alkynones via Carbonylative Sonogashira Coupling ACS Omega 2020, 5, 23687-23702.

24. Koy, M., Bellotti, P., Das, M. N-Heterocyclic carbenes as tunable ligands for catalytic metal surfaces. Nat Catal 2021 , 4, 352-363, https://doi.org/10.1038/s41929-021-00607-z. 
25. Paulina, B.; Katarzyna, S.; Wioletta, K., Michał, M. Acenaphthene-Based N-Heterocyclic Carbene Metal Complexes: Synthesis and Application in Catalysis. Catalysts 2021, 11, 972, https://doi.org/10.3390/catal11080972.

26. Waseem M.; Rami Suleiman, Mohammed Fettouhi, and Bassam El Ali, Soft Heteroleptic N-Heterocyclic Carbene Palladium(II) Species for Efficient Catalytic Routes to Alkynones via Carbonylative Sonogashira Coupling, ACS Omega 2020, 22, 5, 23687-23702.

27. Omrani, R.; Zouaghi, M.O.; Arfaoui, Y. Mechanistic density functional theory study of the Claisen Rearrangement Diels-Alder Cycloaddition domino sequence for the synthesis of the caged garcinia xanthone. J Mol Struct 2020, 1202, 127305, https://doi.org/10.1016/j.molstruc.2019.127305.

28. Chebbi, M.; Arfaoui, Y. Reactivity of pyrazole derivatives with halomethanes: A DFT theoretical study. $J$ Mol Model 2018, 24, 1-10, https://doi.org/10.1007/s00894-018-3718-4.

29. Nida, I.; Munazzah, Y.; Mehwish, J.; Mahvish, A.; Javed, I. Muhammad, A.I. Synthesis in combination with Biological and Computational evaluations of selenium-N-Heterocyclic Carbene compounds. Computational and Theoretical Chemistry 1197, 2021, 113135, https://doi.org/10.1016/j.comptc.2020.113135.

30. Ibrahim, A.; Nedra, T.; Waleed, K.; Tariq, K.; Ismail, Ö.; Sedat, Y.; Naceur, H. Biological Activities of NHCPd(II) Complexes Based on Benzimidazolylidene N-heterocyclic Carbene (NHC) Ligands Bearing Aryl Substituents. Catalysts 2020, 10, 1190, https://doi.org/10.3390/catal10101190.

31. Sylwia, O.; Thomas, S.; Steven, P.N. N-Heterocyclic carbene complexes enabling the $\alpha$-arylation of carbonyl compounds. Chem. Commun 2021, 57, 4354-4375, https://doi.org/10.1039/D1CC00913C.

32. Gara, R. ; Zouaghi, M.O.; ALshandoudi, L.M.H. ; Arfaoui, Y. DFT investigation of solvent, substituent, and catalysis effects on the intramolecular Diels-Alder reaction. $J$ Mol Model 2021,27, 1-12, https://doi.org/10.1007/s00894-021-04729-w.

33. Casida, M.E.; Time-dependent density functional response theory for molecules. World Scientific, Singapore In Recent Advances In Density Functional Methods: (Part I) 1995, 1, 155-192, https://doi.org/10.1142/9789812830586_0005.

34. Bauernschmitt, R.; Ahlrichs, R.. Treatment of electronic excitations within the adiabatic approximation of time dependent density functional theory. Chem Phys Lett 1996, 256, 454-464, https://doi.org/10.1016/00092614(96)00440-X.

35. Tozer, D.J.; Handy, N.C. Improving virtual Kohn-Sham orbitals and eigenvalues: Application to excitation energies and static polarizabilities. J Chem. Phys 1998, 109, 10180-10189, https://doi.org/10.1063/1.477711.

36. Glendening, E.; Reed, A. E.; Carpenter, J. A.; Weinhold, F. NBO Version 3.1.

37. Zouaghi, M.O.; Doggui, M.Y.; Arfaoui, Y. Regio- and stereoselectivity of the [3+2] cycloaddition of nitrones with methyl-acetophenone: A DFT investigation. Journal of Molecular Graphics \& Modelling 2021, 107, 107960, https://doi.org/10.1016/j.jmgm.2021.107960.

38. Le Bahers, T. ; Adamo, C.; Ciofini, I. A qualitative index of spatial extent in charge-transfer excitations . J Chem Theory Comput 2011, 7, 2498-2506, https://doi.org/10.1021/ct200308m.

39. Gaussian 09, Revision A. 02, Frisch, M.J.; Trucks, G.W.; Schlegel, H.B.; Scuseria, G.E.; Robb, M.A.; Cheeseman, J.R.; Scalmani, G.; Barone, V.; Petersson, G.A.; Nakatsuji, H.; Li, X.; Caricato, M.; Marenich, A.; Bloino, J.; Janesko, B. G.; Gomperts, R.; Mennucci, B.; Hratchian, H. P.; Ortiz, J. V.; Izmaylov, A. F.; Sonnenberg, J. L.; Williams-Young, D.; Ding, F.; Lipparini, F.; Egidi, F.; Goings, J.; Peng, B.; Petrone, A.; Henderson, T.; Ranasinghe, D.; Zakrzewski, V. G.; Gao, J.; Rega, N.; Zheng, G.; Liang, W.; Hada, M.; Ehara, M.; Toyota, K.; Fukuda, R.; Hasegawa, J.; Ishida, M.; Nakajima, T.; Honda, Y.; Kitao, O.; Nakai, H.; Vreven, T.; Throssell, K.; Montgomery, J. A.; Jr., Peralta, J. E.; Ogliaro, F.; Bearpark, M.; Heyd, J. J.; Brothers, E.; Kudin, K.N.; Staroverov, V.N.; Keith, T.; Kobayashi, R.; Normand, J.; Raghavachari, K.; Rendell, A.; Burant, J. C.; Iyengar, S. S.; Tomasi, J.; Cossi, M.; Millam, J. M.; Klene, M.; Adamo, C.; Cammi, R.; Ochterski J.W.; Martin, R.L.; Morokuma, K.; Farkas, O.; Foresman, J.B.; Fox, D.J. Gaussian, Inc., Wallingford CT, 2016.

40. Guven, K., Yucel, E., and Cetintas, F., Antimicrobial activities of fruits of Crataegus and Pyrus species .Pharm. Biol. 2006,44, 79-83, https://doi.org/10.1080/13880200600591253.Fernandes CJ, Stevens DA, Groot obbink DJ, Ackerman VP. A replicator method for the combined determination of minimum inhibitory concentration and minimum bactericidal concentration. J Antimicrob Chemother 1985 ,15, 53-60, https://doi.org/10.1093/jac/15.1.53.

41. Özdemir, N.; Touj, N.; Yaşar, S.; Hamdi, N.; Özdemir, İ. Experimental and quantum mechanical investigation on two N-heterocyclic carbene palladium complexes. Mol Cryst Li. Cryst 2021, 714, 26-36, https://doi.org/10.1080/15421406.2020.1848256. 
42. Gayathri, V. ; Pentela, N. ; Samanta, D. Palladium nanoparticles capped by thermoresponsive N-heterocyclic carbene: Two different approaches for a comparative study. Appl Organomet Chem 2021,35, e6166, https://doi.org/10.1002/aoc.6166.

43. Makharza, S.; Auisa, J.; Sharkh, S.A.; Ghabboun, J.; Faroun, M.; Dweik, H.; Sultan, W.; Sowwan, M. Structural and thermal analysis of copper-doped poly (n-isopropylacrylamide) films. Int J Polym Anal Ch 2010, 15, 254-265, https://doi.org/10.1080/10236661003747031.

44. Slimani, I.; Mansour, L.; Özdemir, I.; Gürbüz, N.; Hamdi, N. Synthesis, characterization and catalytic activity of PEPPSI-type palladium-NHC complexes. Inorganica Chim Acta 2021, 515, 120043, https://doi.org/10.1016/j.ica.2020.120043.

45. Shahini, C.R.; Achar, G.; Budagumpi, S.; Tacke, M.; Patil, S.A. Non-symmetrically p-nitrobenzylsubstituted N-heterocyclic carbene-silver (I) complexes as metallopharmaceutical agents. Appl Organomet Chem 2017, 31, e3819, https://doi.org/10.1002/aoc.3819.

46. Song, X.R.; Zheng, Y.; He, G.; Yang, L.; Luo, Y.F.; He, Z.Y.; Li, S.Z.; Li, J.M.; Yu, S.; Luo, X.; Hou, S.X. Development of PLGA nanoparticles simultaneously loaded with vincristine and verapamil for treatment of hepatocellular carcinoma. J Pharm Sci 2010, 99, 4874-4879, https://doi.org/10.1002/jps.22200. 